\title{
Dissecting and Culturing Animal Cap Explants
}

\author{
Kevin S. Dingwell ${ }^{1,2}$ and James C. Smith ${ }^{1,2}$ \\ ${ }^{1}$ The Francis Crick Institute, Developmental Biology Laboratory, London NW1 1AT, United Kingdom
}

The animal cap explant is a simple but adaptable tool available to developmental biologists. The use of animal cap explants in demonstrating the presence of mesoderm-inducting activity in the Xenopus embryo vegetal pole is one of many elegant examples of their worth. Animal caps respond to a range of growth factors (e.g., Wnts, FGF, TGF- $\beta$ ), making them especially useful for studying signal transduction pathways and gene regulatory networks. Explants are also suitable for examining cell behavior and have provided key insights into the molecular mechanisms controlling vertebrate morphogenesis. In this protocol, we outline two methods to isolate animal cap explants from Xenopus laevis, both of which can be applied easily to Xenopus tropicalis. The first method is a standard manual method that can be used in any laboratory equipped with a standard dissecting microscope. For labs planning on dissecting large numbers of explants on a regular basis, a second, high throughput method is described that uses a specialized microcautery surgical instrument.

It is essential that you consult the appropriate Material Safety Data Sheets and your institution's Environmental Health and Safety Office for proper handling of equipment and hazardous materials used in this protocol.

RECIPES: Please see the end of this protocol for recipes indicated by $<R>$. Additional recipes can be found online at http://cshprotocols.cshlp.org/site/recipes.

\section{Reagents}

Agarose

Bovine serum albumin (BSA) (Sigma-Aldrich)

Calcium magnesium-free medium $(\mathrm{CMFM} ; 10 \times)<\mathrm{R}>$

Use this solution at $1 \times$.

Danilchick's for Amy (DFA) $<\mathrm{R}>$

Filter-sterilize. Store in aliquots of $50 \mathrm{~mL}$ at $-20^{\circ} \mathrm{C}$

Gentamycin

High-pressure vacuum grease (Dow)

Marc's modified Ringer's (MMR) $<\mathrm{R}>$

Use this solution at either $0.1 \times$ or $0.7 \times$ supplemented with $50 \mu \mathrm{g} / \mathrm{mL}$ gentamycin.

Recombinant human E-cadherin protein (R\&D Systems 8505-EC-050)

\footnotetext{
${ }^{2}$ Correspondence: kevin.dingwell@crick.ac.uk; jim.smith@crick.ac.uk

From the Xenopus collection, edited by Hazel L. Sive.

(C) 2018 Cold Spring Harbor Laboratory Press

Cite this protocol as Cold Spring Harb Protoc; doi:10.1101/pdb.prot097329
} 
Reusable adhesive putty

Xenopus laevis embryos (dejellied)

See Protocol: Dejellying Xenopus laevis Embryos (Sive et al. 2007a) for dejellying embryos and Introduction: Microinjection of Xenopus Embryos (Sive et al. 2010) for embryo microinjection.

Equipment

Dissecting microscope with a $0.75 \times-10 \times$ objective

Dumont \#5 forceps (Fine Science Tools)

Glass coverslips (\#1.5)

Glass-bottom microwell dishes with No. 1.5 coverglass (35 mm; MatTek P35G-1.5-14-C)

Microcautery instrument with footswitch and pencil tip holder (MC-2010; Protech International Inc.)

Pasteur pipettes (glass)

Petri dishes $(35-50 \mathrm{~mm})$

Wire tip cautery electrode, $1 \mathrm{~mm}$ loop $(13 \mu \mathrm{m}$; 13-Y1; Protech International Inc.)

\section{METHOD}

We routinely use two methods for harvesting animal cap explants. The first is a manual method using fine forceps to dissect the animal cap. The second is a high throughput method that uses a surgical cautery electrode loop to slice off the animal cap. Both methods start with dejellied Xenopus embryos. All dissections are conducted at room temperature $\left(18^{\circ} \mathrm{C}-22^{\circ} \mathrm{C}\right)$.

1. Transfer embryos (stage 8 ) to a $1 \%$ agarose coated Petri dish filled with $0.7 \times$ MMR. Keep several embryos aside in $0.1 \times$ MMR in a standard Petri dish in order to stage the explants. Proceed to Step 2 for the manual method or Step 5 for the electrode method.

The $1 \%$ agarose should be dissolved in the same culture medium that is used to culture the caps (i.e., $0.7 x$ $M M R)$.

\section{Manual Forceps Method}

2. Remove the vitelline envelope from 10-15 embryos using fine forceps (see Protocol: Removing the Vitelline Membrane from Xenopus laevis Embryos [Sive et al. 2007b]). The vitelline envelope is a translucent membrane and is difficult to see so it is best to grasp the envelope with one set of forceps from the vegetal part of the embryo and then pull it away with the other pair. This limits any damage to the animal cap.

3. Dissect an animal cap starting at a region halfway between the animal pole and equator (Fig. 1). This will ensure that no marginal zone tissue (i.e., mesoderm) is acquired during the dissection that could inadvertently affect the differentiation and behavior of the animal cap cells. Using the forceps as "scissors," cut out a "square" animal cap $\left(\sim 0.5 \mathrm{~mm}^{2}\right)$ by a series of successive cuts to free the cap from the embryo. Alternatively, make two simultaneous cuts with both pairs of forceps on opposite sides of the cap, rotate the embryo $90^{\circ}$, and then make the second set of cuts in order to remove the explant.

4. Once all the caps have been excised, wash them by carefully drawing the caps into a glass Pasteur pipette and transferring them to a new $1 \%$ agarose coated dish filled with $0.7 \times$ MMR. It is important not to let the caps come in contact with the surface of the medium as they are extremely delicate and will be destroyed by the surface tension of the solution. Proceed to Step 9, 10,11 , or 12 .

When cultured in $0.7 \times M M R$, the caps "heal" by rounding up into a ball (Fig 1E,F). Since it is the inner cells of the explant that respond to growth factors it is critical to transfer the caps quickly to the culture medium if performing growth factor experiments (Step 10). This ensures that the inner cells are sufficiently exposed to growth factor prior to the cap completely healing (Fig 1). 
K.S. Dingwell and J.C. Smith
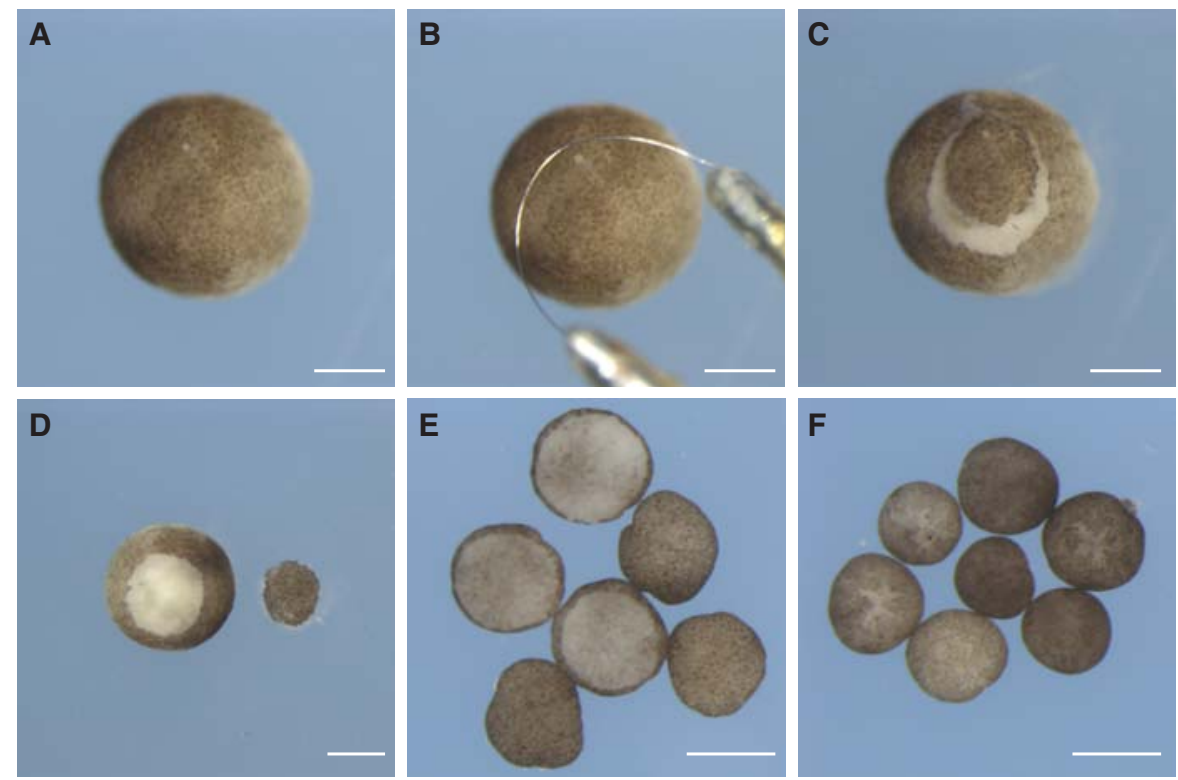

FIGURE 1. Dissecting Xenopus laevis animal caps. Animal cap from a stage 8.5 embryo $(A)$ excised using a $13 \mu \mathrm{m}$ wire tip cautery electrode with a $1 \mathrm{~mm} \operatorname{loop}(B, C)$. Care must be taken to excise only the top half of animal pole $(C, D)$ to ensure that mesoderm is not included with the ectodermal cap. When cultured in $0.7 \times M M R$, caps $(E)$ heal by rounding up into a ball $(F)$. Scale bar: $0.5 \mathrm{~mm}$.

\section{Electrode Method}

This is a high throughput method that enables one to cut hundreds of caps in a single session, and which does not require the removal of the vitelline envelope. If dissociating caps into single cells or live imaging when using this method, the vitelline envelope must be removed before cap cutting. If left on, it tends to stick to the dissociating cells, limiting the number of cells that can be collected.

5. Attach a $13-\mu \mathrm{m}$ loop to the pencil tip that is attached to the main microcautery instrument. When not in use the pencil tip and loop can be held to the top of the instrument using a small amount of reusable adhesive putty.

The loop is extremely delicate and great care should be taken to limit any contact with it.

6. Select power setting 2. A setting higher than 2 limits the life span of the loop.

7. Using a pair of forceps, grasp and hold an embryo submarginally (i.e., just below the equator of the embryo). This keeps the forceps out of the way of the electrode loop. With the loop immersed in the medium, press and hold the foot pedal while simultaneously and in one continuous motion drawing the loop across the top of the embryo to remove the cap (Fig 1). Release the foot pedal. If the cap sticks to the electrode, press the foot pedal until the caps fall off. Repeat for each embryo.

Depending on the speed of cutting, embryonic tissue and/or the vitelline envelope may stick to the loop. It is important to remove this tissue on a regular basis (i.e., after 5 caps) or else the loop cutting efficacy will deteriorate. To remove the tissue, hold the loop in the medium and pulse by pressing and holding the foot pedal until all the tissue is dislodged. We usually pulse between 1 and $3 \mathrm{sec}$. In rare cases when tissue remains stubbornly associated with the loop even after several pulses, it is possible as a last resort to pulse the loop in the air. The "air" pulse should be done for less than half a second or else the tip will be ruined. Pulse again in the medium. Repeat several times if necessary.

8. It is possible to cut explants in batches of 20-30 or even higher depending on the operator's proficiency and their intended use (see note with Step 4). Wash the caps by carefully transferring the caps using a glass Pasteur pipette to a new $1 \%$ agarose coated dish filled with $0.7 \times$ MMR, and then transfer the caps to their final culture dishes (Step 9, 10, 11, or 12). 
9. For standard experiments, culture the explants on $1 \%$ agarose coated dishes at $18^{\circ} \mathrm{C}-21^{\circ} \mathrm{C}$ (in an incubator or on the benchtop) in $0.7 \times$ MMR supplemented with $50 \mu \mathrm{g} / \mathrm{mL}$ gentamycin to inhibit bacterial growth. Keep the caps well separated or they will heal together. Monitor the stage of development by comparing to the control embryos (Step 1).

10. For experiments with growth factors (Jones and Smith 2008), supplement the culture medium $(0.7 \times \mathrm{MMR})$ with $0.1 \% \mathrm{BSA}$ and culture at $18^{\circ} \mathrm{C}-21^{\circ} \mathrm{C}$ until the control embryos have reached the appropriate stage.

The agarose layer should be made as thin as possible as it can act as a sink; too thick and the agarose will deplete the growth factor from the medium and lower its effective concentration.

11. For live imaging experiments, transfer the explant with a Pasteur pipette to a glass bottom microwell dish (these are $35 \mathrm{~mm}$ culture dishes that have a 1.5 coverslip on the bottom) filled with DFA. Hold the cap in place with a coverslip "chip" (see note below) secured with a small amount of high pressure vacuum grease. Special care must be taken when placing the glass chip over the explant so as not to damage the cap with excessive pressure.

DFA (rather than MMR) is used here as its ionic concentration matches the blastocoel fluid of the embryo, and is ideal for maintaining normal cellular behavior and morphogenesis (Keller et al. 1985). Make the glass chips slightly larger than the cap by breaking up a standard coverslip.

12. To dissociate the animal caps into individual cells, transfer them to $1 \times$ CMFM in a $35 \mathrm{~mm} 1 \%$ agarose coated dish (agarose should be made with $1 \times$ CMFM). The inner unpigmented cells should dissociate from the outer pigmented epithelium within 10-20 min. Caps release calcium as they dissociate so limit the number of caps/dish (5-10 caps/35 mm dish). Pipetting the caps through a glass pipette can aid dissociation. Once the inner cells have dissociated, remove the pigmented epithelium and then swirl the medium to aggregate the cells to the center of the dish. Cells can then be either cultured as is, reaggregated in fresh $0.7 \times \mathrm{MMR}$, or cultured in $0.7 \times \mathrm{MMR}$ on $3 \mu \mathrm{g} / \mathrm{mL}$ E-cadherin coated glass bottom microwell dishes for imaging.

To coat the coverslip in the bottom of the microwell dish, treat overnight at $4^{\circ} \mathrm{C}$ with $3 \mu \mathrm{g} / \mathrm{mL}$ of recombinant human E-cadherin protein in $0.7 \times M M R$, and then wash $1 \times$ in $0.7 \times M M R$.

Calcium Magnesium-Free Medium (CMFM)

\begin{tabular}{|c|c|c|}
\hline Reagent & Amount to add & Final concentration \\
\hline $5 \mathrm{M} \mathrm{NaCl}$ & $17.6 \mathrm{~mL}$ & $88 \mathrm{~mm}$ \\
\hline $1 \mathrm{~m} \mathrm{KCl}$ & $1 \mathrm{~mL}$ & $1 \mathrm{~mm}$ \\
\hline $1 \mathrm{M} \mathrm{NaHCO} 3$ & $2.4 \mathrm{~mL}$ & $2.4 \mathrm{~mm}$ \\
\hline 1 м Tris-Cl (pH 7.6) & $7.5 \mathrm{~mL}$ & $7.5 \mathrm{~mm}$ \\
\hline $\mathrm{H}_{2} \mathrm{O}$ & $971.5 \mathrm{~mL}$ & \\
\hline
\end{tabular}

Prepare CMFM from sterile stocks. Store it at room temperature. 
K.S. Dingwell and J.C. Smith

Danilchik's for Amy (DFA) Medium

Reagent

$\mathrm{NaCl}$

$\mathrm{Na}_{2} \mathrm{CO}_{3}$

Potassium gluconate

Sodium gluconate

$\mathrm{CaCl}_{2}$

$\mathrm{MgSO}_{4}$

Bovine serum albumin

Adjust $\mathrm{pH}$ to 8.3 with $1 \mathrm{~m}$ bicine before adding bovine serum albumin. (This recipe is adapted from Sater et al. 1993.)

Marc's Modified Ringer's (MMR) (10×, pH 7.4)

\begin{tabular}{lcc} 
Reagent & Quantity (for 1 L) & Final concentration $(10 \times)$ \\
\hline $\mathrm{NaCl}$ & $58.440 \mathrm{~g}$ & $1 \mathrm{M}$ \\
$\mathrm{KCl}$ & $1.491 \mathrm{~g}$ & $20 \mathrm{~mm}$ \\
$\mathrm{MgSO}_{4}$ & $1.204 \mathrm{~g}$ & $10 \mathrm{mM}$ \\
$\mathrm{CaCl}_{2}$, dihydrate & $2.940 \mathrm{~g}$ & $20 \mathrm{~mm}$ \\
$\mathrm{HEPES}$ & $11.915 \mathrm{~g}$ & $50 \mathrm{~mm}$ \\
$\mathrm{H}_{2} \mathrm{O}$ & to $1 \mathrm{~L}$ &
\end{tabular}

Adjust the $\mathrm{pH}$ to 7.4 using $10 \mathrm{M} \mathrm{NaOH}$. Sterilize by autoclaving. Store at room temperature indefinitely.
Final concentration

$53 \mathrm{~mm}$

$5 \mathrm{~mm}$

$4.5 \mathrm{~mm}$

$32 \mathrm{~mm}$

$1 \mathrm{mM}$

$1 \mathrm{~mm}$

$1 \mathrm{~g} / \mathrm{L}$
Jones CM, Smith JC. 2008. Mesoderm induction assays. In Molecular Embryology. Methods in molecular biology ${ }^{\mathrm{TM}}$ (ed. Sharpe PT, Mason I), Vol. 461. Humana Press.

Keller RE, Danilchik M, Gimlich R, Shih J. 1985. The function and mechanism of convergent extension during gastrulation of Xenopus laevis. J Embryol Exp Morphol 89: 185-209.

Sater AK, Steinhardt RA, Keller R. 1993. Induction of neuronal differentiation by planar signals in Xenopus embryos. Dev Dyn 197: 268-280.
Sive HL, Grainger RM, Harland RM. 2007a. Dejellying Xenopus laevis embryos. Cold Spring Harb Protoc doi: 10.1101/pdb.prot4731.

Sive HL, Grainger RM, Harland RM. 2007b. Removing the vitelline membrane from Xenopus laevis embryos. Cold Spring Harb Protoc doi: $10.1101 /$ pdb.prot4732.

Sive HL, Grainger RM, Harland RM. 2010. Microinjection of Xenopus embryos. Cold Spring Harb Protoc doi: 10.1101/pdb.ip81. 


\section{Dissecting and Culturing Animal Cap Explants}

Kevin S. Dingwell and James C. Smith

Cold Spring Harb Protoc; doi: 10.1101/pdb.prot097329 originally published online May 16, 2018

\begin{tabular}{|c|c|}
\hline $\begin{array}{r}\text { Email Alerting } \\
\text { Service }\end{array}$ & Receive free email alerts when new articles cite this article - click here. \\
\hline $\begin{array}{l}\text { Subject } \\
\text { Categories }\end{array}$ & $\begin{array}{l}\text { Browse articles on similar topics from Cold Spring Harbor Protocols. } \\
\text { Cell Biology, general (1382 articles) } \\
\text { Cell Culture (301 articles) } \\
\text { Cell Imaging (525 articles) } \\
\text { Developmental Biology (728 articles) } \\
\text { Explant Culture (64 articles) } \\
\text { Imaging Development (255 articles) } \\
\text { Imaging/Microscopy, general (579 articles) } \\
\text { Xenopus (210 articles) }\end{array}$ \\
\hline
\end{tabular}

